\author{
ACTA MYCOLOGICA \\ Vol. 43 (2): 193-206 \\ 2008
}

\title{
Distribution of some lichenicolous fungi in Poland. II
}

\author{
KRYSTYNA CZYŻEWSKA ${ }^{1}$, MARIUSZ HACHUŁKA ${ }^{1},{\text { ANNA } \text { ŁUBEK }^{2} \text { and PIOTR ZANIEWSKI }}^{3}$
}

\author{
${ }^{1}$ Department of Mycology, Laboratory of Lichenology, University of Łódź \\ Banacha 12/16, PL-90-237 Łódź, czyzew@biol.uni.lodz.pl \\ ${ }^{2}$ Institute of Biology, Jan Kochanowski University, Świętokrzyska 15 \\ PL-25-406 Kielce, anna.lubek@ujk.kielce.pl \\ ${ }^{3}$ Department of Ecotoxycology, Institute of Experimental Plant Biology \\ Warsaw University, Miecznikowa 1, PL-02-096 Warszawa
}

Czyżewska K., Hachułka M., Łubek A., Zaniewski P. Distribution of some lichenicolous fungi in Poland. II. Acta Mycol. 43(2): 193-206, 2008.

Twenty six species of lichenicolous fungi, one lichenicolous lichen and one lichenicolous myxomycete are discussed. Vouauxiomyces sp., the anamorph of Abrothallus caerulescens, is reported as new to Poland. Abrothallus microspermus is reported from the Polish lowlands for the first time. Trichonectria hirta and Vouauxiomyces truncatus are reported from Poland for the second time.

Key words: Ascomycota, Basidiomycota, conidial fungi, lichenicolous lichen and myxomycete, new records

\section{INTRODUCTION}

This paper continues a review of the lichenicolous fungi recorded in Poland (see Czyżewska 2003a; unnumbered part). Eighty-eight new Polish localities of 28 lichenicolous taxa: 26 lichenicolous fungi (ascomycetes - 9 species, basidiomycetes -3 species and conidial fungi - 14 species, including anamorphs of some lichenicolous ascomycetes), one lichenicolous lichen (Vezdaea aestivalis) and one lichenicolous myxomycete (Licea parasitica), are listed. Vouauxiomyces sp., an anamorph of Abrothallus caerulescens, is reported as new to Poland. Trichonectria hirta and Vouauxiomyces truncatus are reported from Poland for the second time. Abrothallus microspermus is the first lowland record in the country. Abrothallus caerulescens, Arthonia galactinaria, Arthrorhaphis aeruginosa, Chaenothecopsis pusilla, Lichenoconium xanthoriae, Monodictys epilepraria, Taeniolella punctata, Vezdaea aestivalis and Licea parasitica are reported as new to Central Poland. 


\section{MATERIAL AND METHODS}

This study is based on herbarium specimens, mainly the authors `own collections $(1958,1971,1976,1982-1988,1998-2008)$. The material was examined using a Nikon SMZ800 stereomicroscope and a Nikon Eclipse 80i microscope. Routine methods of light microscopy were used: each cross-section was made by hand and mounted in water, potassium hydroxide solution (K), Lugol`s iodine solution (I) and lactophenol picric acid solution. Specimens were identified using the following: Hawksworth (1979, 1981, 1983), Clauzade et al. (1989), Alstrup \& Hawksworth (1990), Diederich (1992, 1996), Santesson \& Tønsberg (1994), Kukwa \& Diederich (2005), Groner (2006) and Ihlen \& Wedin (2008).

Voucher specimens are deposited at the Herbaria LOD, KTC and KRAM-L. All localities are shown in the ATPOL grid square system (Fig. 1).

Abbreviations of collectors names: KC - Krystyna Czyżewska, MH - Mariusz Hachułka, AŁ - Anna Łubek, PZ - Piotr Zaniewski.

\section{LIST OF RECORDED TAXA}

\section{Abrothallus caerulescens Kotte}

This taxon is rare in Poland (see Eichler 1886 as A. parmeliarum; Kukwa \& Czarnota 2006; Kukwa \& Kowalewska 2007; Kukwa \& Jabłońska 2008) while it is common in the neighbouring Czech Republic (Kocourková 2000; see also Svoboda et al. 2008). New to Central Poland.

OBSERVATIONs. Ascomata $0.22-0.30 \mathrm{~mm}$ diam., black, strongly convex, hymenium $40 \mu \mathrm{m}, \mathrm{K}-$, I-, spores 1-septate, brown, 12-14 $\times 4-5 \mu \mathrm{m}$. Associated with its anamorph Vouauxiomyces sp.

Hоsт. Xanthoparmelia conspersa (Ach.) Hale (thallus).

Specimen examined. Dd 77 - Wzniesienia Południowomazowieckie Hights, Wzniesienia Łódzkie Hights, $51^{\circ} 49^{\prime} 7^{\prime} \mathrm{N} / 19^{\circ} 35^{\prime} 37^{\prime \prime} \mathrm{E}$, Grabina Dolna village, on a granite stone in the wall of a historic cemetery, 16 Nov. 2006, leg. MH (LOD 13716).

\section{Abrothallus microspermus Tul.}

The teleomorph A. microspermus is restricted to Flavoparmelia caperata in Poland. The species was known only from old records (Silesia, Koerber 1855; Stein 1879). New to the Polish lowlands.

OBSERVATIONs. Ascomata globose, conspicuous sessile on thallus, strongly convex, black, not pruinose, ca $0.15-0.30 \mathrm{~mm}$ diam. Epithecium brown, hymenium and hypothecium hyaline. Hymenium (and other hyphae) I- and K-. Asci 8-spored, brown, spores 1-septate, 9.6-12 $\times 4.8-5.5 \mu \mathrm{m}$. It was found associated with Vouauxiomyces truncatus (the anamorphic stage of $A$. microspermus).

Host. Flavoparmelia caperata (L.) Hale (thallus).

Specimen examined. Ee 60 - Wyżyna Przedborska Upland, Niecka Włoszczowska Basin, Czarna Pilczycka river valley, 50 $566^{\prime} 50^{\prime} \mathrm{N} / 20^{\circ} 06^{\prime} 24^{\prime \prime} \mathrm{E}$, near “Oleszno" reserve, forest section 73 , in the tree-crown of an old ash in an ash-alder forest, 7 Feb. 2008, leg. AŁ (KTC 8007). 


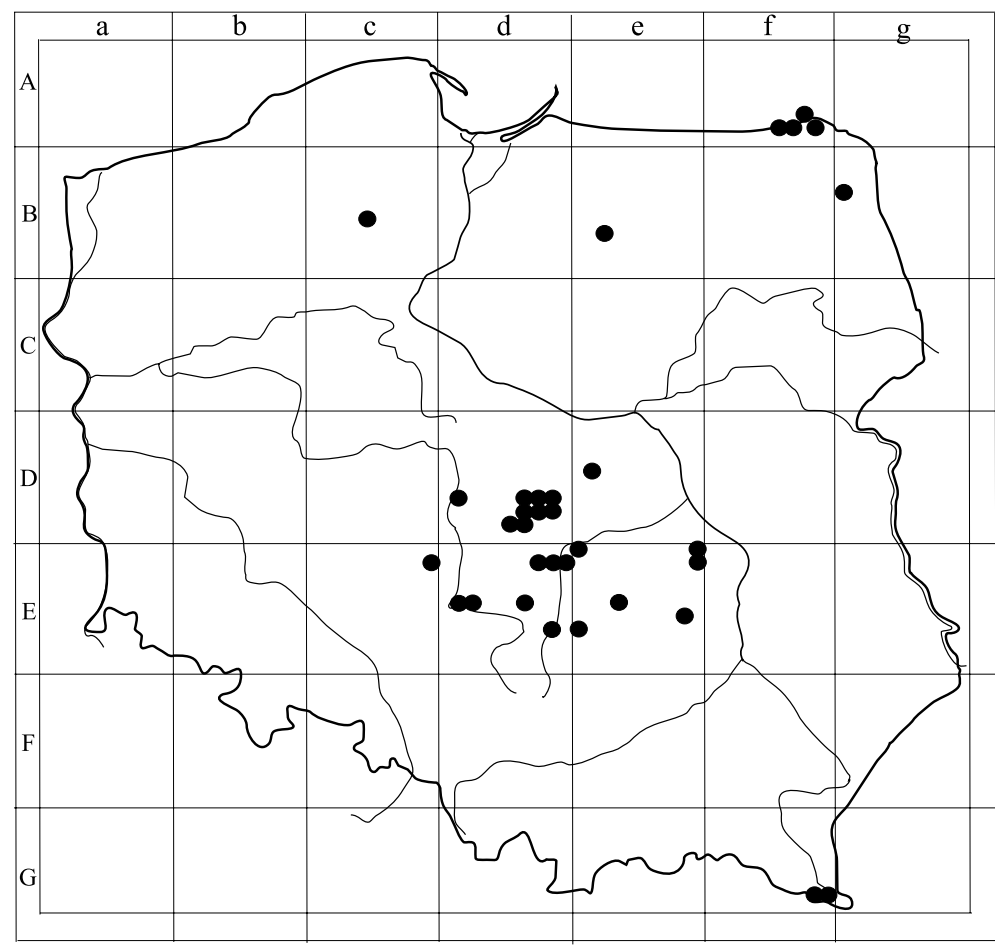

Fig. 1. Location of investigated sites on the ATPOL grid square system.

\section{Arthonia galactinaria Leight.}

The fungus develops in the hymenium of Lecanora dispersa-group species. Recently reported from Poland by Jando \& Kukwa (2001), Kukwa (2004, 2005), Kubiak (2005) and Kukwa \& Jabłońska (2008). A. galactinaria is widespread and common in Europe, and is also known from North America, northern Africa, and New Zealand (cf. Kocourková 2000; Bielczyk et al. 2005; Brackel 2008a). New to Central Poland.

Host. Lecanora hagenii (Ach.) Ach. (apothecia).

Specimen examined. Ed 17 - Wzniesienia Południowomazowieckie Hights, Równina Piotrkowska Plain, Piotrków Trybunalski-Szczekanica town, 51²5'21'N/19³9'10”E, Wojska Polskiego street near 25. Pułku Piechoty street, on the trunk of ash, 5 Jan. 2008, leg. PZ (LOD 15142).

Arthrorhaphis aeruginosa R. Sant. \& Tønsberg

This parasitic fungus is restricted to squamules, rarely podetia of Cladonia spp. and causes specific discolourations of the host tissue. Reported from Poland by Czarnota \& Kukwa (2004), Czyżewska et al. (2005), Kukwa (2005), Kukwa \& Czarnota (2006) and Kukwa \& Kowalewska (2007). New to Central Poland.

Hosts. Cladonia chlorophaea (Sommerf.) Spreng., C. coniocraea (Flörke) Spreng., C. ochrochlora Flörke, Cladonia sp. (squamules). 
Specimens examined. Bc 54 - Pojezierze Południowopomorskie Lakeland, Bory Tucholskie Forests, Suszek, near the Field Station of Łódź University, on Cladonia sp. growing on a decaying log on the forest edge, near a hydrobiological path, 13 Oct. 2000, leg. I. Katucka (LOD 11867, 14534, 14577); Dd 78 - Wzniesienia Lódzkie Hights, 5147’N/19³9'E, Brzeziny forest division, uroczysko Wiączyń range, forest section $174 \mathrm{~b}$, on C. coniocraea growing on a young birch in a forest gap, 26 Oct. 2004, leg. KC (LOD 14570); Ed 18 - Piotrków Trybunalski town, $51^{\circ} 25^{\prime} 31^{\prime \prime} \mathrm{N} / 19^{\circ} 43^{\prime} 42^{\prime \prime} \mathrm{E}$, Las Wolborski Forest, near the road to Meszcze village, on Cladonia sp. growing on the trunk of hornbeam, 12 Jan. 2008, leg. PZ (LOD 15161); Ed 19 Równina Piotrkowska Plain, Nagórzyce forest division, "Lubiaszów" reserve, forest section 120, on Cladonia sp. growing on a very old birch, 27 Sept. 1971, leg. KC (LOD 14502); Ee 09 - Równina Kozienicka Plain, Puszcza Kozienicka Forest, S border of "Ponty Dęby" reserve, on C. coniocraea growing on a very old oak and on Cladonia sp. growing on a decaying stump, 22 Aug. 2006, leg. KC (LOD 14532, 13969), "Załamanek" reserve - the edge, forest section 125, on Cladonia sp. growing on soil along the roadside, 22 Aug. 2006, leg. KC (LOD 15140); Ee 43 - "Skałki Piekło pod Niekłaniem" reserve, on C. ochrochlora and C. coniocraea growing on a decaying oak stump among sandstone rocks, 19 Aug. 2006, leg. KC (LOD 14576); Ee 58 - Wyżyna Kielecka Upland, Przedgórze Iłżeckie, Starachowice forest division, "Rosochacz" reserve, forest section 102d, on Cladonia sp. growing on a strongly decaying stump, 21 Aug. 2006, leg. KC (LOD 15137).

Note. Data from Gałki near Przysucha (Ee 04, 1974, LOD 3427) were reported by Kukwa \& Kowalewska (2007).

\section{Athelia arachnoidea (Berk.) Jülich}

In Poland, the basidiomycete is common on epiphytic lichens and other substrata, mainly in anthropogenic areas (e.g. in cities and disturbed forest sites). Reported from Central Poland by Czyżewska (1998, 2003a, b) and Lubek (2002).

Hosts. Lecanora conizaeoides Cromb., L. carpinea (L.) Vain. (thalli and apothecia), Physcia dubia (Hoffm.) Lettau, Ph. tenella (Scop.) DC., Candelariella xanthostigma (Ach.) Lettau, Scoliciosporum chlorococcum (Stenh.) Vězda, Xanthoria candelaria (L.) Th. Fr. (thalli).

Specimens eXAmined. Dd 61 - Nizina Południowowielkopolska Lowland, Kotlina Sieradzka Basin, 51 ${ }^{\circ} 50^{\prime} \mathrm{N} / 18^{\circ} 45^{\prime} \mathrm{E}$, Leśnik village 85/86, $500 \mathrm{~m}$ E of the Warta river, on L. conizaeoides growing on dry birch branches, in a forest gap, 14 Sept. 2007, leg. M. Sosnowski (LOD 15158); Dd 66 - Wzniesienia Łódzkie Hights, Las Łagiewnicki Forest, forest section 11j, on L. conizaeoides growing on a sycamore, 4 Nov. 2003, leg. MH (LOD 13967), Klęk village near Łódź, on Candelariella xanthostigma growing on a young poplar by the road, $25 \mathrm{Jul}$. 2005, leg. MH (LOD 14753); Dd 76 - Łódź-Stare Bałuty city, Żeglarska street, on Physcia dubia growing on a sycamore, 30 Jul. 2007 and 21 Sept. 2007, leg. KC (LOD 14571, 14572, 14767) (with sclerotia); Dd 78 - Wzniesienia Łódzkie Hights, Brzeziny forest division, uroczysko Wiączyń range, forest sections 161c and 173c, on L. conizaeoides growing on a young Larix decidua, 21 May 2005, leg. A. Olszewska, G. Lipińska \& W. Wesołowska (LOD 14578), 10 Sept. 2004, leg. KC (LOD 14872), forest section $169 \mathrm{~d}$, on L. conizaeoides growing on a young maple, 17 Dec. 2004, leg. A. Olszewska (LOD 14874), forest section 173d, on L. conizaeoides growing on an old fir, 11 Nov. 2005, leg. KC (LOD 14873), 5147’N/19³9’E, “Wiączyń” reserve, forest section 176a, on L. conizaeoides growing on a decaying log, 17 Sept. 2004, leg. KC (LOD 14566); Dd 86 - ŁódźRuda city, uroczysko Ruda-Popioły range, forest section 60, on Scoliciosporum chlorococcum growing on a beech in a Fagus-plantation, 17 Aug. 2004 (field notes, not collected, KC); Ed 17 - Piotrków Trybunalski-Szczekanica town, 51²5'29'N/19³8’39’'E, between Wojska Polskiego and Zawodzie streets on Lecanora carpinea and Xanthoria parietina growing on the trunk of oak, 30 Jan. 2008, leg. PZ (LOD 15171). 


\section{Chaenothecopsis pusilla (Ach.) A.F.W. Schmidt}

Rarely recorded as a lichenicolous fungus in Poland. New to Central Poland. Host. Hypocenomyce scalaris (Ach.) M. Choisy (thallus).

Specimens examined. Bg 30 - Równina Augustowska Plain, Puszcza Augustowska Forest, Studzieniczna-Przewięź near the road to Augustów, on the trunk of a very old pine, 11 Aug. 2007, leg. KC (LOD 14558); Dd 78 - Wzniesienia Łódzkie Hights, 5147’N/19³9'E, "Wiączyń” reserve, forest section 170a, on the trunk of an old oak, 3 Jun., 2006, leg. KC (LOD 15204); De 41 - Nizina Środkowomazowiecka Lowland, Równina Łowicko-Błońska Plain, Puszcza Bolimowska Forest, Grabinka river valley, Radziwiłłów forest division, forest section 28, on the trunk of alder in a wet oak-hornbeam forest, 18 May 1982, leg. KC (LOD 6304); Ee 58 Wyżyna Kielecka Upland, "Rosochacz" reserve, forest section 102d, on the trunk of pine, 28 Aug. 2002, leg. KC (LOD 15135).

Clypeococcum hypocenomycis D. Hawksw.

The species is common in Poland. Also reporeted from Central Poland by Czyżewska (1998, 2003a, b), Łubek (2002) and Kubiak \& Szczepkowski (2006).

Host. Hypocenomyce scalaris (Ach.) M. Choisy (thallus).

Specimens examined. Dd 66 - Wzniesienia Łódzkie Hights, Las Łagiewnicki Forest, forest section 26f, on the trunk of Quercus petraea, 14 Sept. 2003, leg. MH (LOD 15111); Dd 67 - „Struga Dobieszkowska” reserve, forest section $67 \mathrm{j}$, on a young pine in a mixed forest, 14 Jul. 2004, leg. KC (LOD 11905); Dd 68 - uroczysko Tadzin range, forest section 118, on the trunk of pine, 14 Jul. 2004, leg. MH (LOD 14527); Dd 78 - Brzeziny forest division, uroczysko Wiączyń range, forest section 173d, on the trunk of an old fir, 11 Nov. 2005, leg. KC (LOD 14569); Dd 85 - Wysoczyzna Łaska High Plain, Łódź-Lublinek city, uroczysko Lublinek range, forest section 55g, on a birch base near a meadow, 17 Aug. 2004, leg. KC (LOD 15202); Ec 19 - Wysoczyzna Złoczewska High Plain, Sowijaki village near Złoczew, on Pinus sylvestris in a pine forest, 27 Aug. 2006 (field notes, not collected, KC);Ed 18 - Piotrków Trybunalski town, $51^{\circ} 25^{\prime} 32.3^{\prime \prime} \mathrm{N} / 9^{\circ} 45^{\prime} 48.8^{\prime \prime} \mathrm{E}$, Wierzejska street, near the road from Piotrków to Koło village, on the trunk of birch in a pine-plantation, 20 Jan. 2008, leg. PZ (LOD 15179); Ed 19 - Równina Piotrkowska Plain, Tresta Rządowa village, on the bark of a decaying stump in a pine plantation, 3 Jul. 2005, leg. MH (LOD 15132); Ee 09 - Puszcza Kozienicka Forest, „Ponty” reserve, forest section 48, near a forest road, on the trunk of an old pine, 22 Aug. 2006, leg. KC (LOD 14614), „Załamanek” reserve, forest section 125, on the trunk of pine, 21 Aug. 2006, leg. KC (LOD 14613); Ee 43 - Wyżyna Kielecka Upland, Garb Gielniowski, „Skałki Piekło pod Niekłaniem” reserve, on the trunk of an old pine, 19 Aug. 2006, leg. KC (LOD 14550); Ee 58 - Starachowice forest division, „Rosochacz” reserve, forest section 102d, on the trunk of an old pine, 21 Aug. 2006, leg. KC (LOD 15138); Ee 60 - Niecka Włoszczowska Basin, 50 58'16”N $/ 20^{\circ} 050^{\prime} 30^{\prime} \mathrm{E}$, „Oleszno” reserve, forest section 54, on the trunk of oak, 25 May 2008 (field notes, not collected, AŁ).

Graphium aphtosae Alstrup \& D. Hawksw.

This peltigericolous fungus was relatively recently described by Alstrup \& Hawksworth (1990) from Greenland and Norway on Peltigera aphtosa. The species is known from neighbouring Lithuania (Motiejūnaitè et al. 2008), Estonia (Suija 2005) and Russia (Alstrup 2004). According to Suija (2005), this saprotrophic fungus has always been associated with other obligate or facultative lichenicolous fungi (e.g. Thelocarpon epibolum, Sarcosagium campestre, Corticifraga fuckelii and Pronectria robergei). Rare in Poland, previously known from two sites in N Poland (see Kukwa 
\& Adamska 2006) and in the Western Carpathians - High Tatra Mts (Kukwa \& Jabłońska 2008). It is the third record from the Polish lowlands.

Host. Peltigera rufescens (Weiss) Humb. (thallus).

Specimen eXamined. Ed 42 - Wyżyna Wieluńska Upland, Działoszyn-Grądy village, on soil in the psammophilous grassland between a road and a mixed forest, associated with Vezdaea aestivalis, 15 Jun. 1998, leg. J. Żelazna-Wieczorek, det. J. Miadlikowska, 1998 (LOD 10335).

\section{Illosporium carneum Fr.}

The anamorph of Pronectria robergei. A common peltigericolous fungus, known from numerous localities in Poland; often together with Pronectria robergei. Reported from Central Poland by Lubek (2002) and Czyżewska (2003a, b).

Host. Peltigera didactyla Fr. (thallus).

Specimen examined. Af 77 - Pojezierze Litewskie Lakeland, Pojezierze Wschodniosuwalskie Lakeland, $54^{\circ} 23^{\prime} 31.9^{\prime \prime} \mathrm{N} / 22^{\circ} 50^{\prime} 35.8^{\prime \prime} \mathrm{E}$, Stankuny village near the NW part of Lake Wiżajny, on soil in the psammophilous grassland along the roadside, together with Pronectria robergei, 17 Jul. 2008, leg. PZ (LOD 15187).

Intralichen christiansenii (D. Hawksw.) D. Hawksw. \& M.S. Cole

This hyphomycete mostly grows on apothecia of Candelariella aurella and Lecanora dispersa-group, rarely on other host species. This conidial fungus is widely distributed in continental Europe, but has also been reported from North Africa and North America. Reported from Central Poland by Lubek (2002) and Czyżewska (2003a, b).

Hosts. Candelariella aurella (Hoffm.) Zahlbr., Lecanora dispersa (Pers.) Sommerf., Lecidella elaeochroma (Ach.) Choisy (apothecia).

Specimens eXAmined. Af 86 - Pojezierze Litewskie Lakeland, Puszcza Romincka Forest, S edge of "Boczek" reserve, forest section 146, on Lecidella elaeochroma growing on the trunk of aspen in a bog alder forest, 16 May 1985, leg. Z. Tobolewski \& S. Cieślinski (LOD 14152); Dd 66 - Wzniesienia Łódzkie Hights, 5149'16”N/19³4'48”E, Bukowiec village, Bukowa 66, on a concrete pillar, 10 May 2005, leg. MH (LOD 12300); Dd 68 - Poćwiardówka, on mortar in a wall along the road, 25 Nov. 2005, leg. MH (LOD 13920); Ed 17 - Piotrków Trybunalski town, $51^{\circ} 24^{\prime} 26.4^{\prime \prime} \mathrm{N} / 19^{\circ} 41^{\prime} 05.3^{\prime \prime} \mathrm{E}$, Narutowicza street, near new railway viaducts, on C. aurella and L. dispersa growing on concrete, 20 Jan. 2008, leg. PZ (LOD 15178).

\section{Licea parasitica (Zukal) Martin}

This myxomycete is often found growing on epiphytic lichens, especially physcioid ones. According to Kocourková (2000), this facultatively lichenicolous myxomycete is often found in nitrophilous conditions. Reported in Poland by Jando \& Kukwa (2003), Kukwa (2004, 2005), Kukwa \& Czarnota (2006) and Kukwa \& Jabłońska (2008). Species new to Central Poland.

Host. Physcia tenella (Scop.) DC. (thallus).

Specimen eXamined. Ed 18 - Piotrków Trybunalski town, 51²5’31”N/1943'42”E, Las Wolborski Forest, near the road to Meszcze village, on the trunk of hornbeam, 12 Jan. 2008, leg. $P Z$ (LOD 15160). 
Lichenoconium erodens M.S. Christ. \& D. Hawksw.

One of most common lichenicolous parasites, known from many localities in Poland on various hosts and very often recorded in anthropogenic sites. Reported from Central Poland by Czyżewska (1998, 2003a, b) and Lubek (2002).

Hosts. Hypocenomyce scalaris (Ach.) M. Choisy, Lecanora conizaeoides Cromb. (thalli).

Specimens examined. Dd 61 - Kotlina Sieradzka Basin, 5150'N/1845'E, Leśnik village 85/86, $500 \mathrm{~m} \mathrm{E}$ of the Warta river, on L. conizaeoides growing on a pine in a pine forest, 14 Sept. 2007, leg. KC (LOD 14961); Dd 66 - Wzniesienia Łódzkie Hights, Las Łagiewnicki Forest, forest section 10f, on H. scalaris growing on the trunk of birch, 17 Oct. 2003, leg. $M H$ (LOD 14850), forest section 26, on $H$. scalaris growing on the trunk of oak, 30 Oct. 2007, leg. MH (LOD 14837); Dd 67 - "Struga Dobieszkowska" reserve, forest section 67j, on L. conizaeoides growing on the trunk of pine in a mixed forest, 14 Jul. 2004, leg. KC (LOD 11879), forest section 76a, on L. conizaeoides growing on oak, 3 Nov. 2003, leg. MH (LOD 15112); Dd 68 - Wzniesienia Łódzkie Hights, uroczysko Tadzin range, forest section 116a, on L. conizaeoides growing on the trunk of an old beech, 21 Apr. 2004, leg. MH (LOD 14524); Dd 85 - Łódź-Lublinek city, uroczysko Lublinek range, forest section 54y, on L. conizaeoides growing on an old pine in a mixed forest, forest section $54 \mathrm{j}$, the same, forest section $55 \mathrm{~b}$, on L. conizaeoides growing on a birch, 17 Aug. 2004, leg. KC (LOD 15190, 15194, 15193); Dd 86 - Łódź-Ruda city, uroczysko Ruda-Popioły range, forest section 60a, on L. conizaeoides growing on the trunk of spruce in an oak-hornbeam forest, $17 \mathrm{Aug}$. 2004, forest section 58h, on $L$. conizaeoides growing on a pine, 17 Aug. 2004, leg. KC (LOD 15192, 15191); Ed 17 - Piotrków Trybunalski-Wiślana town, 51²4'04'N/1941'29”'E, the edge of J. Poniatowski Park near Zeromskiego street, on H. scalaris growing on the trunk of oak, 1 Dec. 2007, leg. PZ (LOD 15143), 51'25'27.8'N/19³9'31.1'E, between Pawłowska, Piwnika and Świtalskiego streets, on L. conizaeoides growing on a birch in a pine forest, 30 Jan. 2008, leg. PZ (LOD 15172).

\section{Lichenoconium lecanorae (Jaap) D. Hawksw.}

A common lichenicolous fungus, known from various localities in Poland, often in pine-plantations. Reported from Central Poland by Czyżewska (1998, 2003a, b), Łubek (2002) and Kubiak \& Szczepkowski (2006).

Host. Lecanora conizaeoides Cromb. (apothecia).

Specimens examined. Dd 61 - Kotlina Sieradzka Basin, 5150’N/1845'E, Leśnik village 85/86, $500 \mathrm{~m}$ E of the Warta river, on a pine in a pine forest, 14 Sept. 2007, leg. KC (LOD 14960), on dry birch branches in a forest gap, 14 Sept. 2007, leg. A. Sosnowska (LOD 15156); Dd 66 - Wzniesienia Lódzkie Hights, Las Łagiewnicki Forest, forest section 11i, on the trunk of an old alder near the Łagiewniczanka stream, 4 Nov. 2003, leg. MH (LOD 14511); Dd 67 "Struga Dobieszkowska" reserve, forest section 76, on a pine in a mixed forest, 14 Jul. 2004, leg. KC (LOD 11906), uroczysko Janinów range, forest section 39a, on an old oak, 6 Oct. 2004, leg. MH (LOD 14672); Dd 68 - uroczysko Tadzin range, forest section 110b, on a pine, 3 Jun. 2004, leg. $M H$ (LOD 14515), forest section 118, on pine bases, 14 Jul. 2004, leg. MH (LOD 14516); Dd 77 - near Polik village, 5148'22'N/1941'39'”E, on a young ash, 27 Sept. 2005, leg. MH (LOD 14517); Dd 78 - Brzeziny forest division, uroczysko Wiączyń range, forest section 155f, on an old pine near path, 7 May 2005, leg. KC (LOD 14605), forest sections 157a, 164a, on an old beech, 14 Oct. 2004, leg. KC (LOD 14601), the edge of forest section 169d, on a young maple, 17 Dec. 2004, leg. A. Olszewska (LOD 14603), forest section 173d, on an old fir, 11 Nov. 2005, leg. KC (LOD 14600), forest section 176c, on a very old oak, 3 Oct. 2004, leg. KC (LOD 14602), forest section 180a, on hornbeam twigs, 17 Oct. 2004, leg. $K C$ (LOD 14870), forest section 191b, on an old spruce, 9 Sept. 2005, leg. KC (LOD 14599), forest section 191d, on a young Quercus rubra, 9 Sept. 2005, leg. KC (LOD 14604); Dd 85 
- Łódź-Lublinek city, uroczysko Lublinek range, forest section 55b on a birch, forest section $54 y$, on an old pine in a mixed forest, 17 Aug. 2004, leg. KC (LOD 15189, 15190); Ec 19 - Wysoczyzna Złoczewska High Plain, Sowijaki village near Złoczew, on a pine in a pine forest, 27 Aug. 2006 (field notes, not collected, KC); Ed 17 - Piotrków Trybunalski-Szczekanica town, 51'25'29'N/19³8'39.4'E, Wojska Polskiego street near Zawodzie street, on the trunk of oak, 30 Jan. 2008, leg. PZ (LOD 15170); Ee 09 - Równina Kozienicka Plain, near "Ponty" reserve, forest section 48, on the trunk of an old pine, 22 Aug. 2006, leg. KC (LOD 15159, 15162), S border of "Ponty Dęby" reserve, on twigs of a very old Quercus robur, 22 Aug. 2006, leg. KC (LOD 15163); Ee 19 - Równina Kozienicka Plain, "Jedlnia" reserve near a tourist hotel, on a very old pine in a mixed forest, 22 Aug. 2006, leg. KC (LOD 15164); Ee 43 - Wyżyna Kielecka Upland, „Skałki Piekło pod Niekłaniem” reserve, on an old pine near sandstone rocks, 19 Aug. 2006, leg. KC (LOD 14546).

Lichenoconium pyxidatae (Oudem.) Petr. \& Sydow.

Common on podetia of Cladonia spp., but probably overlooked (cf. Motiejūnaite and Czyżewska 2008). Reported from Central Poland by Łubek (2002) and Czyżewska (2003a, b).

Hosts. Cladonia coniocraea (Flörke) Spreng., C. ochrochlora Flörke, C. fimbriata (L.) Fr. (podetia).

Specimens eXAmined. Be 62 - Pojezierze Olsztyńskie Lakeland, Stawiguda village, $3.5 \mathrm{~km}$ SE of the village, forest section 167 in a mixed forest, on $C$. fimbriata growing on soil, 19 Jul. 1988, leg. S. Cieśliński, det. M. Kukwa, 2005 (KTC in LOD 14717); Dd 78 - Wzniesienia Łódzkie Hights, Brzeziny forest division, uroczysko Wiączyń range, forest section 174b, on $C$. coniocraea growing on the bark of a dead young birch, 8 Nov. 2004, leg. KC (LOD 14606); Ed 41 - Wyżyna Wieluńska Upland, near the Ogroble settlemnt, on C. fimbriata growing in the psammophilous grassland, 20 Jul. 1976, leg. KC, det. M. Kukwa 2005 (LOD 14544); Ee 09 Puszcza Kozienicka Forest, near „Załamanek” reserve, forest section 125, on C. ochrochlora growing on soil along the roadside, 22 Aug. 2006, leg. KC (LOD 15139).

\section{Lichenoconium xanthoriae M.S. Christ.}

This coelomycete has been reported from ten localities in Poland (see Kukwa \& Motiejūnaitè 1999; Jando \& Kukwa 2001, 2003; Kukwa et al. 2002; Sparrius 2003; Kukwa 2004, 2005; Kukwa \& Czarnota 2006; Kukwa \& Jabłońska 2008). New to Central Poland.

ObSERvations. Pycnidia 100-200 $\mu \mathrm{m}$ diam., conidia $4.5 \mu \mathrm{m}$ diam.

Host. Xanthoria polycarpa (Hoffm.) Rieber (apothecia).

Specimen examined. Ee 60 - Niecka Włoszczowska Basin, 5056'42”N 2006'17”E, “Oleszno" reserve, forest section 79, in an ash tree-crown in a wet situation, 7 Feb. 2008, leg. AE (KTC 8010).

\section{Monodictys epilepraria Kukwa \& Diederich}

This conidial fungus, recently described by Kukwa and Diederich (2005), is restricted to Lepraria spp. M. epilepraria is known from Austria, the Czech Republic, Estonia, Great Britain, Lithuania, Poland, Spain, Sweden and Slovenia (cf. Kukwa \& Diederich 2005; Kukwa 2008). According to Kukwa and Jabłońska (2008) the species is virtually absent in polluted areas, even if host lichens are very common, therefore it seems that the occurrence of $M$. epilepraria is limited by air pollution. New to Central Poland.

Hosts. Lepraria incana (L.) Ach., Lepraria sp. (thalli). 
Specimens examined. Ed 46 - Wysoczyzna Bełchatowska High Plain, Bełchatów forest division, uroczysko Pytowice range, forest section 212, on the trunk of oak in an oak-hornbeam forest, 19 Sept. 1982, leg. KC, det. M. Kukwa, 2006 (LOD 14503); Ee 60 - Niecka Włoszczowska Basin, "Oleszno" reserve, forest section 53/54, on L. incana growing on the trunk of sycamore in a wet situation, 25 May 2008, leg. AŁ (KTC 8134).

Phaeopyxis punctum (A. Massal.) Rambold, Triebel \& Coppins

Reported from Central Poland only by Czyżewska (2003b).

Hosts. Cladonia digitata (L.) Hoffm., Cladonia sp. (squamules).

Specimens exAmined. Ee 09 - Równina Kozienicka Plain, "Załamanek" reserve, forest section 125, near reserve, on soil along the roadside, 22 Aug. 2006, leg. KC (LOD 14536); Ee 60 - Niecka Włoszczowska Basin, „Oleszno” reserve, forest section 60, an oak base in a wet situation, 25 May 2008, leg. At (KTC 8135).

Pronectria robergei (Mont. \& Desm.) Lowen

In Poland, this peltigericolous ascomycete was reported by Zielińska (1963), Kukwa (2004, 2005), Kukwa \& Jabłońska (2008) and Motiejūnaitė \& Czyżewska (2008). The species is known from the countries adjancent to Poland, the Czech Republic (Kocourková 2000), Lithuania (Motiejūnaitè 2007) and also Russia (Zhurbenko 2008).

Host. Peltigera didactyla (With.) J.R. Laundon (thallus).

SPECIMEN EXAMINED. Af 77 - Pojezierze Wschodniosuwalskie Lakeland, $54^{\circ} 23^{\prime} 31.9^{\prime \prime} \mathrm{N} / 22^{\circ} 50^{\prime} 35.8^{\prime \prime} \mathrm{E}$, Stankuny village near the NW part of Lake Wiżajny, on soil along the roadside in the psammophilous grassland, 17 Jul. 2008, leg. PZ (LOD 15169).

\section{Syzygospora physciacearum Diederich}

This physcyicolous fungus is known in Poland only from north and north-east (Czyżewska et al. 2001; Kukwa et al. 2002; Kukwa 2004, 2005; Kukwa \& Jabłońska 2008). The species is quite frequent both in Lithuania and Estonia (Suija 2005; Suija et al. 2007; Motiejūnaitè et al. 2008).

Host. Physcia tenella (Scop.) DC. (thallus).

SPeCimen eXAmined. Af 88 - Pojezierze Wschodniosuwalskie, 5420'49.6”N 2254'25.9”N, Kamionka village, near the Wiżajny-Rudka Tartak serpentine road, on the trunk of willow, 24 Jul. 2008, leg. PZ (LOD 15176).

Note. Also reported from grid square Af 88 by Kukwa \& Jabłońska (2008): in the Suwalski Landscape Park, S of Smolniki village, 54 16 '55'N/22 53'02'E, between Lakes Jaczno and Kojle, on Ph. tenella.

\section{Taeniolella beschiana Diederich}

This fungus is restricted to Cladonia spp. The species is known mainly from northern regions of Europe, North America, and Asia as well as from Central and Western Europe (e.g. Ihlen \& Wedin 2006; Brackel 2008a). According to Diederich (1992; see also Suija 2005) it is similar to T. delicata, differing in the surface structure of the conidia and in host preferences. T. delicata was reported in Poland by Kukwa et al. (2008) only from Białowieża National Park, on Loxospora elatina.

Hosts. Cladonia coniocraea (Flörke) Spreng., C. subulata (L.) F.H. Wigg. (squamules). 
Specimen examined. Ee 09 - Puszcza Kozienicka Forest, "Ponty" reserve, forest section 48, on the trunk of a very old oak, 22 Aug. 2006, leg. KC (LOD 15154).

Note. Reported from Central Poland by Czyżewska (2003b). The following localities: Równina Kurpiowska Plain, Dobrylas village [Cf 01, 1985, LOD 14608], Wysoczyzna Białostocka High Plain, Białystok-Bagnówka town [Cg 11, 1983, LOD 12057], Równina Bielska Plain, Kleszczele-Piaski village [Cg 72, 1987, LOD 9003], Równina Opolska Plain, between Murów and Mańczok villages [Ec 97, 1984, LOD 7501], Niecka Włoszczowska Basin, Łabędź village near Koniecpol town [Ed 77, 1969, LOD 14609], were reported by Kukwa \& Kowalewska (2007).

Taeniolella punctata M.S. Christ. \& D. Hawksw.

This conidial fungus is restricted to Graphis scripta and occurs mainly in oldgrowth forests. It is known from neighbouring Ukraine (Bielczyk et al. 2005), Lithuania (Motiejūnaitė \& Andersson 2003) and Estonia (Suija 2005; Suija et al. 2007). The species was reported in Poland by Jando \& Kukwa (2003), Czyżewska et al. (2005), Kukwa (2005), Kukwa \& Czarnota (2006), Kukwa \& Jabłońska (2008) and Szymczyk \& Zalewska (2008). New to Central Poland.

Host. Graphis scripta (L.) Ach. (apothecia and thallus).

Specimens examined. Af 85 - Pojezierze Litewskie Lakeland, Puszcza Romincka Forest, forest section 88, on the trunk of elm in a wet fertile oak-linden-hornbeam forest, 16 May 1985, leg. S. Cieśliński \& Z. Tobolewski (LOD 14046); Ed 19 - Równina Piotrkowska Plain, Nagórzyce forest division, „Lubiaszów” reserve, forest section 120, on the trunk of an old hornbeam in an oak-hornbeam forest, 27 Sept. 1971, leg. KC (LOD 11932); Ed 68 - Niecka Włoszczowska Basin, 50 55'N/1944'E, „Dębowiec” reserve, forest section 162, on the trunk of an old linden, 23 Apr. 1969, leg. KC (LOD 15168); Ee 00 - Równina Piotrkowska Plain, Lasy Spalskie Forest, "Spała" reserve, forest section 286, on the trunk of an old hornbeam, 22 Aug. 1970, leg. KC (LOD 15166).

\section{Tremella lichenicola Diederich}

Reported from Central Poland by Łubek (2002) and Czyżewska (2003a, b).

Host. Mycoblastus fucatus (Stirt.) Zahlbr. (thallus).

Specimen examined. Ee 60 - Niecka Włoszczowska Basin, 5058'08’N/ 2005’46”'E, „Oleszno" reserve, forest sections 53/54, on the trunk of sycamore, 7 Feb. 2008, leg. AŁ (KTC 8012).

\section{Trichonectria hirta (A. Bloxam) Petch}

Reported by Kukwa \& Czarnota (2006) on Micarea prasina and Placynthiella dasaea. It is the second record of this hypocrealen fungus in Poland.

OBSERvATIONS. Ascospores vermiform, hyaline, 14-24-septate, 48-80 × 4.5-5,8 $\mu \mathrm{m}$, ends obtuse. Ascomata (perithecia) pale orange with stiff white hairs, ca $250 \mu \mathrm{m}$ diam.

Host. Scoliciosporum chlorococcum (Stenh.) Vĕzda (thallus).

Specimen examined. Ee 60 - Niecka Włoszczowska Basin, 5056'42’'N/ 2006’17’'E, „Oleszno" reserve, forest section 79, on the base of an ash trunk in an ash-alder forest, 7 Feb. 2008, leg. AŁ (KTC 8001). 
Vezdaea aestivalis (Ohlert) Tscherm.-Woess \& Poelt

The species is quite rare in Poland (Fałtynowicz 2003), reported as a lichenicolous lichen only by Miądlikowska \& Alstrup (1995). New to Central Poland.

Host. Peltigera rufescens (Weiss) Humb. (thallus).

SPecimen eXAmined. Ed 42 - Wyżyna Wieluńska Upland, Dzialoszyn-Grądy village, on soil in the psammophilous grassland between a road and a mixed forest, associated with Graphium aphtosae, 15 Jun. 1998, leg. J. Żelazna-Wieczorek, det. J. Miadlikowska, 1998 (LOD 10335).

Vouauxiella lichenicola (Linds.) Petr. \& Syd.

This species is frequent in Poland, though overlooked.

Host. Lecanora pulicaris (Pers.) Ach. (thallus and apothecia).

SPecimens eXamined. Ee 60 - Niecka Włoszczowska Basin, 5056’54”-56’42”N/ 2006’43”06'17'E, “Oleszno" reserve, forest section 73, on the trunk and tree-crown of an ash, forest section 79, the same, 11 Mar. and 7 Feb. 2008, leg. AE (KTC 8011, 8013).

Vouauxiomyces truncatus (B. de Lesd.) Dyko \& D. Hawksw.

The anamorph of Abrothallus microspermus is known from several countries in Nothern, Western and Central Europe (see Brackel 2008b). This is the second record in Poland (see Kukwa 2005).

ObSERVATIONs. Pycnidia ca $3 / 4$ submerged in thallus, globose, black, with a distinct ostiole, $0.15-0.17 \mathrm{~mm}$ diam. Conidial spores obpyriform, hyaline, 5.8-8.6(-10) $\times$ 3.8-4.8(-6) $\mu \mathrm{m}$. It was found associated with Abrothallus microspermus in "Oleszno" reserve.

Host. Flavoparmelia caperata (L.) Hale (thallus).

SPecimens eXAmined. Ee 09 - Nizina Środkowomazowiecka Lowland, Równina Kozienicka Plain, Puszcza Kozienicka Forest, „Ponty” reserve, forest section 48, on the bark of an old oak, 22 Aug. 2006, leg. KC (LOD 14543); Ee 60 - Niecka Włoszczowska Basin, „Oleszno” reserve, on the trunk of ash in a wet situation, 10 Oct. 2005, leg. S. Cieśliński (KTC 8008); for-

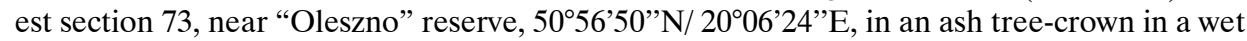
situation, 7 Feb. 2008, leg. AŁ (KTC 8007); Gf 68 - Eastern Carpathians, Bieszczady Zachodnie Mts, Puszcza Bukowa Forest, Dział, S slope, alt. $850 \mathrm{~m}$, on the bark of a lying beech in a beech forest, 19 Aug. 1958, leg. K. Glanc (KRAM-L 38934); Gf 69 - Bieszczady Zachodnie Mts, Magura Stuposiańska Mt., SW slope, alt. 920 m, on limbs of a lying beech, 23 Sept. 1958, K. Glanc (KRAM-L 38938), Bukowe Berdo Mt., N slope, alt. $850 \mathrm{~m}$, on the trunk of beech in a beech forest, 11 Aug. 1958, leg. K. Glanc (KRAM-L 38956).

Vouauxiomyces sp. - anamorph of Abrothallus caerulescens Kotte

This taxon has been reported by Kocourková (2000) from the Czech Republic on thalli of Xanthoparmelia conspersa and $X$. stenophylla growing on a granite boulder and also from Russia (Polar part) on X. stenophylla (Zhurbenko 2008). New to Poland.

Observations. Pycnidia 50-54 $\mu \mathrm{m}$ diam. Conidia obpyriform, hyaline, $6.4-8(-10)$ $\times 4.8-6 \mu \mathrm{m}$, associated with Abrothallus caerulescens.

Host. Xanthoparmelia conspersa (Ach.) Hale (thallus).

Specimen examined. Dd 77 - Wzniesienia Lódzkie Hights, 5149'7’N/19³5'37'E, Grabina Dolna village, growing on a granite stone in the wall of a historic cemetery, near the road, 16 Nov. 2006, leg. $M H$ (LOD 13716). 
Xanthoriicola physciae (Kalchbr.) D. Hawksw.

A very common lichenicolous fungus, known from many European countries and northern Africa, also known from numerous localities in Poland.

Host. Xanthoria parietina (L.) Th. Fr. (apothecia).

SPECIMEN EXAMINED. Af 88 - Pojezierze Wschodniosuwalskie Lakeland, $54^{\circ} 20^{\prime} 49.6^{\prime} \mathrm{N} / 22^{\circ} 54^{\prime 25.9}$ 'E, Kamionka village, near the Wiżajny-Rudka Tartak serpentine road, on a dead willow twig, 24 July 2008, leg. PZ (LOD 15175).

\section{CONCLUSIONS}

The genus Abrothallus and its anamorphic stage seem to be particularly interesting in this study. Species belonging to the genus are underexplored in Poland and are mostly known from old records only (cf. Fałtynowicz 2003), for instance A. cetrariae (only its anamorph Vouauxiomyces santessonii is known; cf. Czyżewska et al. 2005; Kukwa \& Czarnota 2006 and Kukwa \& Jabłońska 2008), A. parmeliarum (only its anamorph Voauxiomyces sp. is known; see Kukwa et al. 2002), A. peyritschii and $A$. prodiens.

It would be recommended to review the hosts, almost exclusively macrothalli and common lichens in Poland, for instance Parmelia saxatilis, P. sulcata, Hypogymnia physodes, Platismatia glauca, Vulpicida pinastri as well as Melanelia s.lat. and Xanthoparmelia spp., for the occurrence of Abrothallus spp. and its anamorphic stages (Vouauxiomyces spp.).

Acknowledgements. The authors are indebted to the anonymous reviewer for suggestions on the manuscript and to Dr. Jurga Motiejūnaitè (Vilnius) for valuable comments on the manuscript. We also thank Dr. hab. Lucyna Śliwa (Kraków) for the loan of some specimens (KRAM-L). The study was supported by the Polish Ministry of Science and Higher Education, grants Nos 2 PO4G 06930 and N305 04332.

\section{REFERENCES}

Alstrup V. 2004. New records in distribution of lichens and lichenicolous fungi. Graphis Scripta 15: 4657.

Alstrup V., Hawksworth D.L. 1990. The lichenicolous fungi of Greenland. Meddr. Grønland, Biosci. 31: $1-90$.

Bielczyk U., Bylińska E., Czyżewska K., Guzow-Krzemińska B., Hachułka M., Kiszka J., Kowalewska A., Krzewicka B., Kukwa M., Leśniański G., Śliwa L., Zalewska A. 2005. Contribution to the knowledge of lichens and lichenicolous fungi of Western Ukraine. Pol. Bot. J. 50 (1): 39-64.

Brackel von W. 2008a. Phoma ficuzzae sp. nov. and some other lichenicolous fungi from Sicily, Italy. Sauteria 15: 103-120.

Brackel von W. 2008b. Some lichenicolous fungi collected during the 20th meeting of the Societa Lichenologica Italiana in Siena. Not. Soc. Lich. Ital. 21: 63-66.

Clauzade G., Diederich P., Roux C. 1989. Nelikeniĝintaj fungoj likenoloĝaj. Ilustrita determinlibro. Bull. Soc. Linn. Provence, Numéro Spécial 1: 1-142.

Czarnota P., Kukwa M. 2004. Some sorediate lichens and lichenicolous fungi new to Poland. Graphis Scripta 15: 24-32. Stockholm.

Czyżewska K. 1998. Lichenized Ascomycotina of the Bełchatów Industrial Region (Central Poland). Acta Mycol. 33 (2): 341-366.

Czyżewska K. 2003a. Distribution of some lichenicolous fungi in Poland. Acta Mycol. 39 (1-2): 111-122.

Czyżewska K. 2003b. Lichens and lichenicolous fungi in the Bolimów Landscape Park. Monogr. Bot. 92: 233-277. 
Czyżewska K., Motiejūnaitė J., Cieśliński S. 2001. Species of lichenized and allied fungi new to Białowieża Large Forest (NE Poland). Acta Mycol. 36 (1): 13-19.

Czyżewska K., Motiejūnaitė J., Cieśliński S. 2005. New and noteworthy species of lichens and allied fungi from North-Eastern Poland. Acta Mycol. 40 (2): 277-291.

Diederich P. 1992. New or interesting lichenicolous fungi 2. Taeniolella beschiana sp. nov. and Taeniolella serusiauxii sp. nov. (Hyphomycetes). Bull. Soc. Nat. luxemb. 93: 155-162.

Diederich P. 1996. The lichenicolous heterobasidiomycetes. Biblioth. Lichenol. 6: 1-198.

Eichler B. 1886. Spis porostów znalezionych w okolicach Międzyrzecza. Pam. Fizjogr. 6: 251-268.

Fałtynowicz W. 2003. The lichens, lichenicolous and allied fungi of Poland. An annotated checklist. (In:) Z. Mirek (ed.). Biodiversity in Poland 6. W. Szafer Institute of Botany, Polish Academy of Sciences, Kraków, 435 pp.

Groner U. 2006. The genus Chaenothecopsis (Mycocaliciaceae) in Switzerland, and key to the European species. Lichenologist 38 (5): 395-406.

Hawksworth D.L. 1979. The lichenicolous Hyphomycetes. Bull. Brit. Mus. (Nat. Hist.), Bot. 6: 183-300.

Hawksworth D.L. 1981. The lichenicolous Coelomycetes. Bull. Brit. Mus. (Nat. Hist.), Bot. 9 (1): 1-98.

Hawksworth D.L. 1983. A key to the lichen-forming, parasitic and saprophytic fungi occurring on lichens in the British Isles. Lichenologist 15: 1-44.

Ihlen P.G., Wedin M. 2006. Notes on two lichenicolous fungi on Cladonia botrytes in Scandinavia. Graphis Scripta 18: 13-40.

Ihlen P.G., Wedin M. 2008. An annotated key to the lichenicolous Ascomycota (including mitosporic morphs) of Sweden. Nova Hedwigia 86 (3-4): 275-365.

Jando K., Kukwa M. 2001. Lichens and lichenicolous fungi of the "Mewia Lacha" nature reserve in the month of Vistula river (Northern Poland). (In:) A.A. Zavarzin, O.V. Petrova, A.V. Sonina, V.N. Tarasova (eds), Proceedings of the first Lichenological Field Meeting Apatity, 2000, p. 279-288. Petrozavodsk State University, Petrozavodsk.

Jando K., Kukwa M. 2003. Porosty, grzyby naporostowe i nażywiczne projektowanego rezerwatu "Wiszące Torfowiska nad jeziorem Jaczno" w Suwalskim Parku Krajobrazowym (Północno-Wschodnia Polska). Parki nar. Rez. Przyr. 22 (1): 3-17.

Kocourková J. 2000. Lichenicolous fungi of the Czech Republic (The first commented checklist). Acta Mus. Nat. Pragae, Ser. B, Hist. Nat. 55 (3-4)[1999]: 59-169.

Koerber G. 1855. Systema lichenum Germaniae. Die Flechten Deutschland, inbesondere Schlesiens. Verl. Trevendt \& Granier, Breslau, 459 pp.

Kubiak D. 2005. Lichens and lichenicolous fungi of Olsztyn town (NE Poland). Acta Mycol. 40 (2): 293332.

Kubiak D., Szczepkowski A. 2006. Lichens of the Rogów Forest of Warsaw Agricultural University (1): Arboretum, Popień and Zimna Woda reserves. Ann. Warsaw Agrucult. Univ. - SGGW, For. and Wood Technol. 60: 51-63.

Kukwa M. 2004. New or interesting records of lichenicolous fungi from Poland II. Species mainly from northern Poland. Herzogia 17: 67-75.

Kukwa M. 2005. New or interesting records of lichenicolous fungi from Poland III. Herzogia 18: 37-46.

Kukwa M. 2008. Monodictys epilepraria, a lichenicolous fungus new to Slovenia. Herzogia 21: 233-234.

Kukwa M., Adamska E. 2006. Stanowiska dwóch interesujących gatunków grzybów naporostowych znalezionych na Peltigera spp. w Polsce. Fragm. Florist. Geobot. Polonica 13 (1): 197-201.

Kukwa M., Czarnota P. 2006. New or interesting records of lichenicolous fungi from Poland IV. Herzogia 19: 111-123.

Kukwa M., Diederich P. 2005. Monodictys epilepraria, a new species of lichenicolous hyphomycetes on Lepraria. Lichenologist 37 (3): 217-220.

Kukwa M., Jabłońska A. 2008. New or interesting records of lichenicolous fungi from Poland VI. Herzogia 21: 167-179.

Kukwa M., Motiejūnaitė J. 1999. Some new of noteworthy lichenicolous fungi to Poland. Fragm. Florist. Geobot. 44 (2): 491-497.

Kukwa M., Kowalewska A. 2007. New or interesting records of lichenicolous fungi from Poland. Species mainly on Cladonia V. Herzogia 20: 199-207.

Kukwa M., Motiejūnaitė J., Rutkowski P., Zalewska A. 2002. New or interesting records of lichenicolous fungi from Poland I. Herzogia 15: 129-139. 
Kukwa M., Schiefelbein U., Czarnota P., Halda J., Kubiak D., Palice Z., Naczk A. 2008. Notes on some noteworthy lichens and allied fungi found in the Białowieża Primeval Forest in Poland. Bryonora 41: 1-11.

Łubek A. 2002. Contribution to lichenicolous fungi from the Świętokrzyski National Park (Central Poland). Acta Mycol. 37 (1-2): 93-100.

Miądlikowska J., Alstrup V. 1995. Some peltigericolous fungi and lichens mainly from Poland. Graphis Scripta 7 (1): 7-10.

Motiejūnajtė J. 2007. Lichenized, lichenicolous and allied fungi of Žemaitija National Park (Lithuania). Herzogia 20: 179-188.

Motiejūnaite J., Andersson L. 2003. Contribution to the Lithuanian flora of lichens and allied fungi. Botanica Lithuanica 9 (1): 71-88.

Motiejūnaitė K., Czyżewska K. 2008. Additions to the biota of lichens and lichenicolous fungi of Poland with note on Lecania prasinoides in Eastern and Central Europe. Pol. Bot. J. 53 (2): 155-162.

Motiejūnaitė J., Alstrup V., Randlane T., Himelbrant D., Sončius D., Hermansson J., Urbanavichus G., Suija A., Fritz Ö., Prigodina Lukošiene I., Johansson P. 2008. New or noteworthy lichens and allied fungi from Biržai district, Lithuania. Botanica Lithuanica 14 (1): 29-42.

Santesson R., Tønsberg T. 1994. Arthrorhaphis aeruginosa and A. olivaceae, two new lichenicolous fungi. Lichenologist 26: 295-299.

Sparrius L. 2003. Contribution to the lichen flora of the Białowieża Forest and the Biebrza valley (Eastern Poland). Herzogia 15: 155-160.

Stein B. 1879. Flechten. (In:) Cohn`s Kryptogamenflora von Schlesien. Jahrb. Schles. Ges. Vaterl. Cult. 2.2: $1-400$.

Suija A. 2005. Lichenicolous fungi in Estonia II. Basidiomycota and conidial fungi. Nova Hedwigia 80 (3-4): 349-365.

Suija A., Löhmus P. Jüriado I. 2007. The lichen biota of the Agusalu and Puhatu reserves (Estonia): the first overview. Forestry Studies 47: 99-116.

Svoboda D., Bouda F., Halda J.P., Kukwa M., Liška J., Maliček J., Müller A., Palice Z., Peksa O., Szymczyk R., Schiefelbein U. 2008. Lišejniky zaznamenané bĕhem 14. Jarniho setkáni Bryologicko-Lichenologické sekce ČBS na exkurzich na vyškovsku na Moravě. Bryonora 41: 12-20.

Szymczyk R., Zalewska A. 2008. Lichen biota of the Grabinka river valley in the Elblagg Upland (Wysoczyzna Elbląska). Pol. J. Natur. Sci. 23 (2): 398-414.

Zielińska J. 1963. O kilku pasożytach z rodzaju Peltigera Pers. Monogr. Bot. 15: 427-432.

Zhurbenko M. 2008. Lichenicolous fungi from Russia, mainly ftom its Arctic. II. Mycologia Balcanica 5: $13-22$.

Rozmieszczenie wybranych grzybów naporostowych w Polsce. II

\section{Streszczenie}

W pracy przedstawiono 28 taksonów grzybów naporostowych (26 gatunków) oraz porostów (Vezdaea aestivalis) i śluzowcow (Licea parasitica) naporostowych. Gatunki te występowały na 88 nowych stanowiskach zlokalizowanych w Polsce Północnej, Środkowej i Południowej (Fig. 1). Badane materiały są zdeponowane w herbariach LOD, KTC i KRAM-L. Wśród rozpoznanych gatunków, Vouauxiomyces sp. (anamorfa Abrothallus caerulescens) jest taksonem nowym dla Polski, a Trichonectria hirta i Vouauxiomyces truncatus (anamorfa Abrothallus microspermus) stwierdzono po raz drugi w kraju. Abrothallus microspermus, znany tylko ze starych notowań na Śląsku (Koerber 1855; Stein 1879), został tutaj podany po raz pierwszy z niżu polskiego. Gatunkami nowymi dla Polski Środkowej są: Abrothallus caerulescens, Arthonia galactinaria, Arthorhaphis aeruginosa, Chaenothecopsis pusilla, Lichenoconium xanthoriae, Monodictys epilepraria, Taeniolella punctata, Vezdaea aestivalis i Licea parasitica. 